\title{
Conservation implication and traditional ecological knowledge on trading bird: A case study in Depok bird market in Surakarta, Central Java, Indonesia
}

\author{
FEBRIANA KINANTHI PUTRI ${ }^{1}$, FITRI ALICIA ${ }^{1}$, HELENA JOAN NOVEN ${ }^{1}$, MUCHAMMAD SHOLIQIN ${ }^{1,}$ \\ WIDHI HIMAWAN ${ }^{1}$, REVIDO AJI JAVARENDRA ${ }^{1}$, NOR LIZA ${ }^{2}$, RUHYAT PARTASASMITA ${ }^{3, *}$, \\ JOHAN ISKANDAR ${ }^{3}$, DARLINA MD. NAIM ${ }^{4}$, AHMAD DWI SETYAWAN ${ }^{1,5, \%}$ \\ ${ }^{1}$ Department of Environmental Science, Faculty of Mathematics and Natural Sciences, Universitas Sebelas Maret. Jl. Jend. Urip Sumoharjo No. 179, \\ Surakarta 57128, Central Java, Indonesia. Tel.: +62-271-663375, `email: volatileoils@gmail.com \\ ${ }^{2}$ Biodiversitas Study Club, Department of Biology, Faculty of Mathematics and Natural Sciences, Universitas Sebelas Maret. Jl. Ir. Sutami 36A Surakarta \\ 57126, Central Java, Indonesia \\ ${ }^{3}$ Department of Biology, Faculty of Mathematics and Natural Sciences, Universitas Padjadjaran. Jl. Raya Bandung-Sumedang Km 2.1 Jatinangor, \\ Sumedang 45363, West Java, Indonesia. * pass away \\ ${ }^{4}$ School of Biological Sciences, Universiti Sains Malaysia. 1112, Persiaran Sains, 11800 Gelugor, Pulau Pinang, Malaysia \\ ${ }^{5}$ Biodiversity Research Group, Universitas Sebelas Maret. Jl. Ir. Sutami 36A, Surakarta 57126, Central Java, Indonesia
}

Manuscript received: 4 September 2021. Revision accepted: 30 November 2021.

\begin{abstract}
Putri FK, Alicia F, Noven HJ, Sholiqin M, Himawan W, Javarendra RA, Liza N, Partasasmita R, Iskandar J, Naim DM, Setyawan AD. 2021. Conservation implication and traditional ecological knowledge on trading bird: A case study in Depok bird market in Surakarta, Central Java, Indonesia. Biodiversitas 22: 5636-5648. Bird species have been the most popular animals in Indonesia for such a long time. Therefore, the demand for birds has been rising in urban area. The bird species are usually traded, including selling and buying activities in urban bird markets. The increase of bird trading in Indonesia also increased the economic and social benefits for Indonesian people. Consequently, there is a chance that many bird trading in bird markets are not managed carefully, without preventing the bird species extinction in rural ecosystems. This paper aimed to assess the conservation status of birds sold and the Traditional Ecological Knowledge (TEK) of bird traders in Depok bird market in Surakarta (Solo), Central Java, Indonesia. The study used a qualitative method with the ethnoornithological approach. The results showed that the diversity of birds encountered in the bird market of Depok was considered high, 55 species were recorded, representing 29 families. Seven bird species are protected by Indonesian law while 12 species are considered endemic. Moreover, 8 birds are included in IUCN Red List. The bird naming is based on particular categories that are agreed on in local community. Furthermore, social involvement through education and local wisdom might have profound impact on conservation efforts to preserve the bird population.
\end{abstract}

Keywords: Bird market, Depok bird market, status conservation, traditional ecological knowledge

\section{INTRODUCTION}

Birds are one of the most frequently traded animals in the world (Burivalova et al. 2017). The demand for birds by some people becomes a market opportunity for traders and bird catchers to gain economic benefits. In order to fulfill the needs of bird demand, traders always try to provide birds to buyers. The upwards trend in catching and selling bird species threatens bird population in Asia, with Indonesia as the epicenter of songbird crisis (Nijman et al. 2021b). This fact is reasonable as data acquired from Nijman et al. (2019) showed approximately tens of thousands of birds caught from the wild were sold in the markets in Java Island each day. Various efforts have been made to get a supply of birds, resulting in bird catching that can threaten the existence of birds in nature.

There are various reasons why people keep birds, such as respect in their community, and for cultural, entertainment and economic reasons (Mutiara et al. 2020). Birds can be used as inspiration for artwork, for state symbols, as clothing motifs, kept in cages for hobbies, etc.
(Ghifari et al. 2016). Bird keeping is closely related to local traditions, including social and cultural life. In Javanese tradition, keeping cage-bird is considered a hobby, as well as achievement and status symbols (Chng et al. 2016; Nijman and Nekaris 2017). Moreover, that study also suggested that keeping particular bird species is a way to bring fortune and to show wealth status. However, there was no statistical data that support the mentioned relation between keeping bird and socioeconomic aspects (Alves et al. 2013). Another case in China's ethnic community showed that the major reason for keeping birds is finding sense of enjoyment, but some people refuse to do that and prefer bird watching (Dai et al. 2021).

Bird trade is often carried out in bird markets. The rise of the bird markets in Indonesia has both positive and negative impacts. There are two types of bird markets known in Indonesia, namely open and closed (black) bird markets. An open bird market is a bird market that visually appears as a market where sellers and buyers meet. The hallmark of an open market is that animals are deliberately installed with all their charms to attract as many consumers 
as possible. Meanwhile, a closed bird market is an animal market that provides animals for sale, but offers and transactions are carried out in private. Usually, the closed bird market offers endangered species which should not be traded because they are protected by law (Haryanta 2011). Moreover, bird trade can also take place on online marketplace platforms. Based on study conducted in Thailand, there was a similarity between bird prices offered on online marketplace and in physical market (Siriwat and Nijman 2020). Besides the drawback it brings, online market has a benefit compared to the offline market. Online activities can be easily monitored by the authorities and conservationists as there are data about bird species being traded (Fink et al. 2021). That study also stated that online shop platforms might provide valuable information to the potential customers, such as conservation status of birds they want to purchase.

Various species of birds are natural resources that are included in the renewable category. According to Iskandar (2014), bird populations in nature experience dynamics at any time depending on the intake rate and output rate factors of bird population stocks. The intake factor means the chicks or breeding rate of the bird. Meanwhile, the output rate means the rate of decline in bird population, due to bird mortality, the effect of various causes, such as aging and/or disease, due to environmental pressures from increasing human activities (Rumanasari et al. 2017; Nurdin et al. 2018) such as habitat destruction and/or loss, the consequences of poaching of birds to be raised, traded and contested in cities. Therefore, it is necessary to make efforts to preserve birds so that they can be beneficial in a sustainable manner. In fact, bird-keeping in Indonesia has been at a level that requires conservation practice such as marketbased conservation because Indonesia is assumed to be quite active in bird economy (Jepson and Ladle 2005;
Indraswari et al. 2020). There are several conservation efforts that can be done by humans as a form of responsibility for the preservation of bird species such as broadening discipline for conservation and developing social science experience (Newing et al. 2011). The existence of birds in a tourist area requires conservation efforts by providing education to tourists who come (Kamaludin et al. 2019).

Ethno-ornithology as a trans discipline has evolved over the past several decades, bringing together nature conservation and the TEK system in ecological management and biodiversity conservation (Pam 2017). It leads to forming common or vernacular names that are only based on community's imagination, or, in other words, without systematization (Loss et al. 2014). Moreover, it is suggested that conservation effort through ethno-ornithological approach is the realistic method as it involves local knowledge system (Alcantara-Salinas et al. 2013). This paper aimed to determine the conservation status and Traditional Ecological Knowledge (TEK) of bird traders on bird species traded, based on a case study in Depok bird market, Surakarta (Solo), Central Java, Indonesia. We desire that this paper contributes to policymaking and effective measures regarding conservation of bird species.

\section{MATERIALS AND METHODS}

\section{Study sites}

This study took place in bird market of Depok, Surakarta (Solo), Central Java, Indonesia from December 2020 to January 2021. Depok bird market is located on Jalan Depok No. 14, Manahan, Banjarsari, Surakarta City, with administrative boundary maps of the city shown in Figure 1.
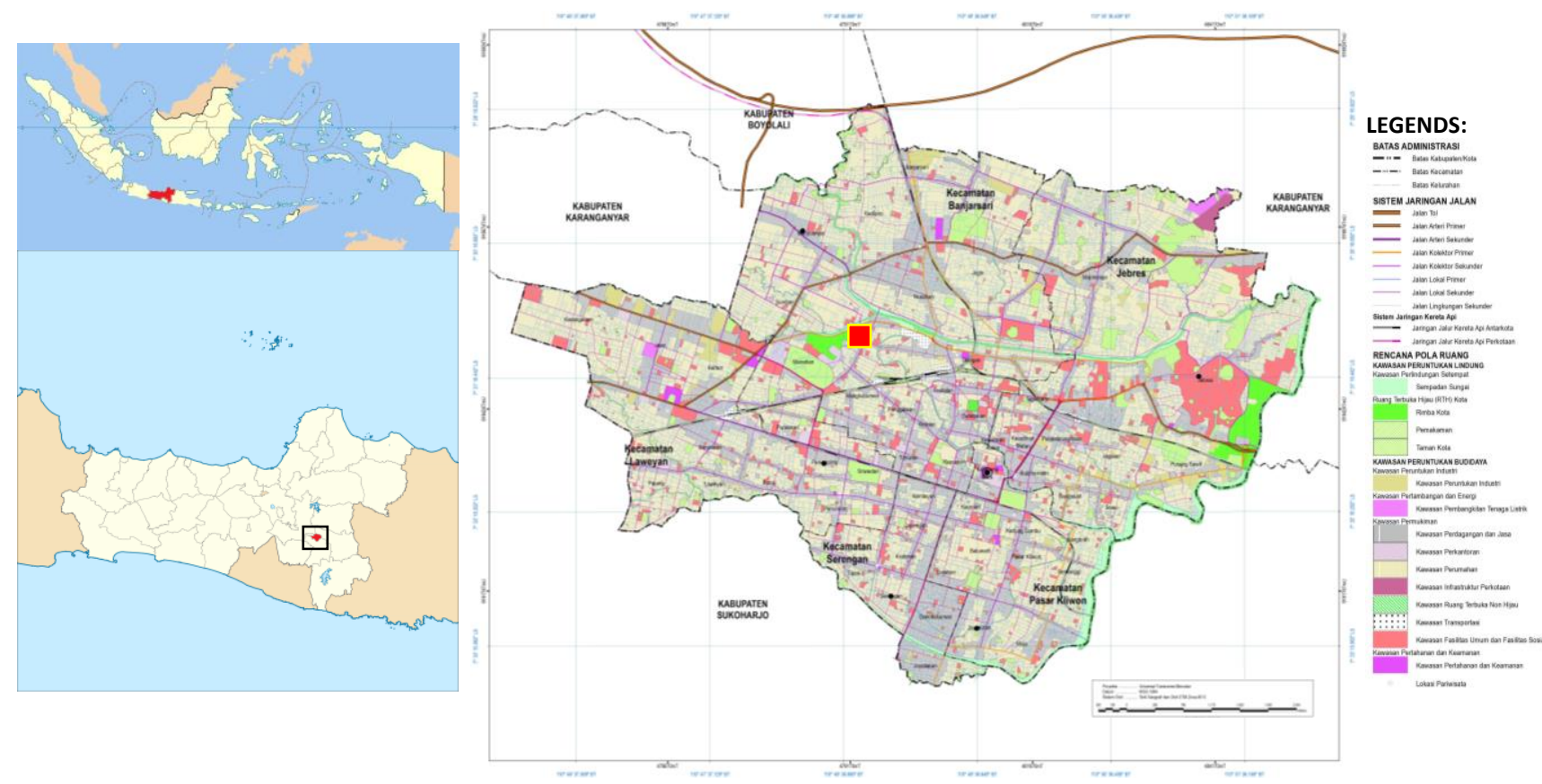

Figure 1. Study area in Depok bird market (ロ), Surakarta, Central Java, Indonesia (Bappeda Surakarta, https://intip.surakarta.go.id/album-peta) 
Surakarta City is geographically located between latitudes of $7^{\circ} 36^{\prime} 00^{\prime \prime}$ and $7^{\circ} 49^{\prime} 30^{\prime \prime}$ "South and between longitudes of $110^{\circ} 45^{\prime} 15^{\prime \prime}$ and $110^{\circ} 45^{\prime} 35$ East. Depok bird market is geographically located at $7^{\circ} 33^{\prime} 09.0^{\prime \prime} \mathrm{E}$ and $110^{\circ} 48^{\prime} 37.7 \mathrm{~S}$. This market has a total area of $17.662 \mathrm{~m}^{2}$ and consists of 3 zones, which are the front zone, the side zone, and the back zone (Figure 2). Besides birds as the main selling point, this market also provides various other pets, such as rabbits, cats, and dogs.

According to direct survey, Depok bird market has 481 traders, consisting of 64 stall traders, 226 non-permanent stall traders, and 183 traders without stalls. The other facilities found in this market are 5 toilets, 1 praying place, and 1 security post. The species of birds traded in Depok bird market are usually kept in cages placed inside the stalls. The bird cages are usually taken out from the stalls and hung in front of the stall in order to let the birds get the morning sunlight. During the daytime, the bird cages are moved to a place with a little sunlight. In the afternoon, the birdcages will be put in the closed stall. Besides selling bird species, the bird traders also sell various tools and utensils such as nest boxes, cages, wooden sticks or bamboo bird perches, bird foods, medicines, vitamins, and others sold in the stalls (Figure 3). Other activities in the bird market, include selling and buying birds and others can be seen in Figure 4)

\section{Research procedures}

This study used qualitative with ethnoornithology approach method, which is a branch of ethnozoology merged from the ethnosciences field to seek and understand people's different perspectives and interaction with faunal or avifaunal resources through history. The ethnoornithology focused on the TEK or the Local Knowledge (LK) of birds, also culturally mediated relationships between communities and other animals in the environment. Local people's knowledge begins with animal nomenclature and classification in the local idiom.

\section{Bird survey/observation}

The study collected data from the field using some techniques such as observation/survey and semi-structured interviews. Observation was used in order to observe the general condition of the Depok bird market. For observation the researchers visited the Depok market firstly in the morning, when every bird trader started to work or began to open the stalls, also to take out the bird cages or hang them. This observation consisted of two methods: (i) participant observation in which researchers were actively involved in some activities of bird traders, including providing bird foods, and (ii) non-participant observation in which researchers observed the general condition of bird market and various activities of bird traders' and buyers' activities. The field research observations took about 2 months. Firstly, the researchers visited bird traders to introduce themselves and to ask for permission to do the research on the bird market; this included asking the local authority of the bird market service for permission. In this survey species, diversity and its abundance are counted and photographed. Bird species with more than 100 individuals are categorized as dominant.

\section{In-depth interview}

The semi-structured interview or can be called in-depth interview was used with competent respondents purposively selected by using snowball technique. This snowball technique was used to explore who are the suitable competent informants or the local expert as bird traders in the Depok market's bird trader community. Therefore, the researchers could choose the local experts who represented the individuals who are socially legitimized and have particular knowledge. The steps started with the initial contact with the bird trader community, identified the first expert, and after that this expert indicated another expert, until all the Depok's bird market community experts were involved. Researchers interviewed 15 people consisting of 10 sellers, three buyers, and two people who acted as middlemen. All are male. The average age level of these respondents is between 20 and 53 years old. In these semi-structured interviews, people were asked about the species of birds being sold, the origin/source of the birds being sold, the price, the popularity of the birds being traded and the profits earned (Figure 5). The interview information was recorded using a voice note and field notebook.

\section{Data analysis}

Primary data of this study were obtained from observation/survey and semi-structured interviews. The predominant semi-quantitative data and non-numerical data-most commonly either words or pictures were analyzed, which made critical analysis and construction of a narrative count. The qualitative analysis involved crosschecking, summarizing, and synthesizing from sources to build up a narrative account. Cross-checking was undertaken by checking data to validate data, namely researchers used triangulation that is comparing the data of observations/surveys with data obtained from interviews. The researcher compared the interview data from one informant to another. Bird species were identified using Mackinnon et al. (2010). The conservation status of the birds was referred to IUCN RedList (Kasambe 2014; https://www.iucnredlist.org/) and Appendix II of CITES (cites.org) for international status, as well as Indonesian Ministry of Environment and Forestry Regulation (Permen LHK No. P.20/MENLHK/setjen/Kum.1/6/2018) for national status.

\section{RESULTS AND DISCUSSION}

\section{Bird species traded}

Direct observation/survey and interview with bird traders managed to record 55 bird species, representing 29 families sold in the bird market of Depok (Table 1). The bird diversity in the bird market of Depok was slightly higher than that of bird market in Bogor, West Java (54 species) but lower than that of bird market of Pasty, Yogyakarta (106 species) (Iskandar et al. 2020). This result is also less than studies in the Sukahaji bird market, 
Bandung (128 species) and the Splendid bird market, Malang (116 species) (Iskandar et al. 2019).

In addition, the ratio of dominant and non-dominant bird species is similar (27 and 28 species respectively). Some of the non-dominant species are protected species. Therefore, it can be inferred that although some birds in Indonesia have been protected, there is no guarantee that those species can survive in their natural habitat or ecosystem because illegal hunting and trade in rare and protected bird species continue in many regions (Hakim et al. 2020).
The most common birds traded in this market were of family Muscicapidae, consisting of 7 species (Figure 5), followed by Columbidae, Pycnonotidae, Sturnidae, and Timaliidae that shared the same number (4 species), then Cuculidae, Pistacidae, Psitttaculidae, and Turdidae only represented by 2 species. Moreover, the rest families only consisted of one species each. A similar result from a study carried out in several local markets in Laos found that the largest number of species traded belong to family Muscicapidae (Xayyasith et al. 2020).

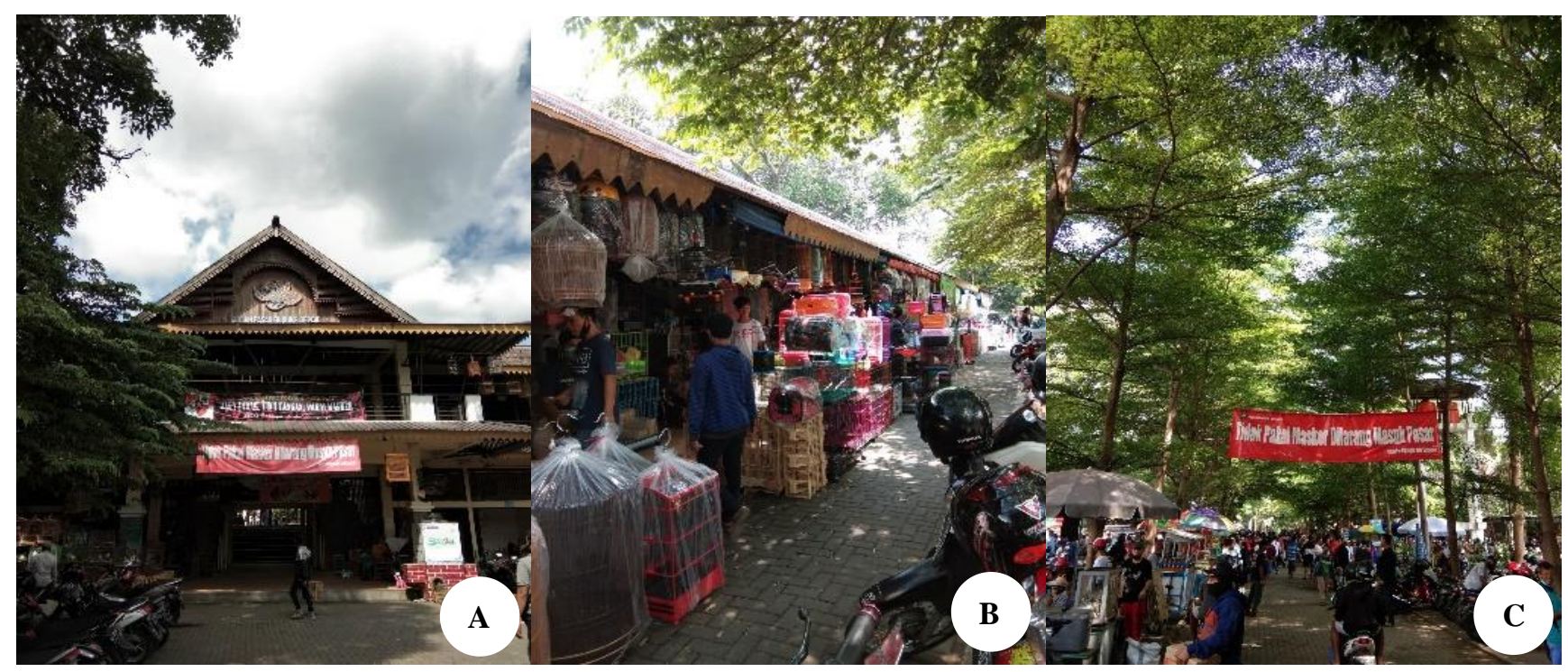

Figure 2. A. The front zone; B. the side zone; and C. the back zone of Depok bird market, Surakarta, Central Java, Indonesia

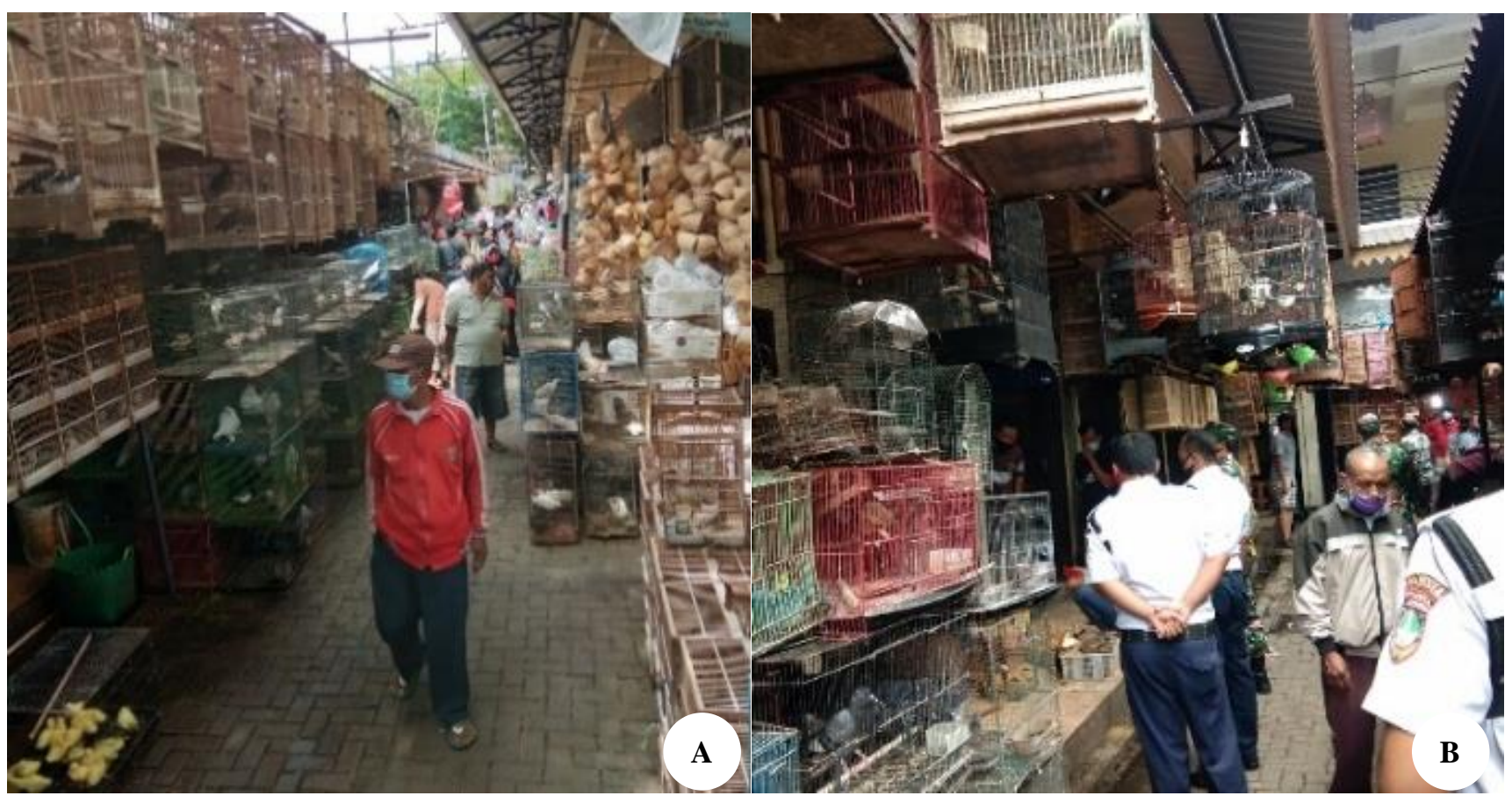

Figure 3. A. Birds are put in the cages; B. various products that are sold in Depok Depok bird market, Surakarta, Central Java, Indonesia 


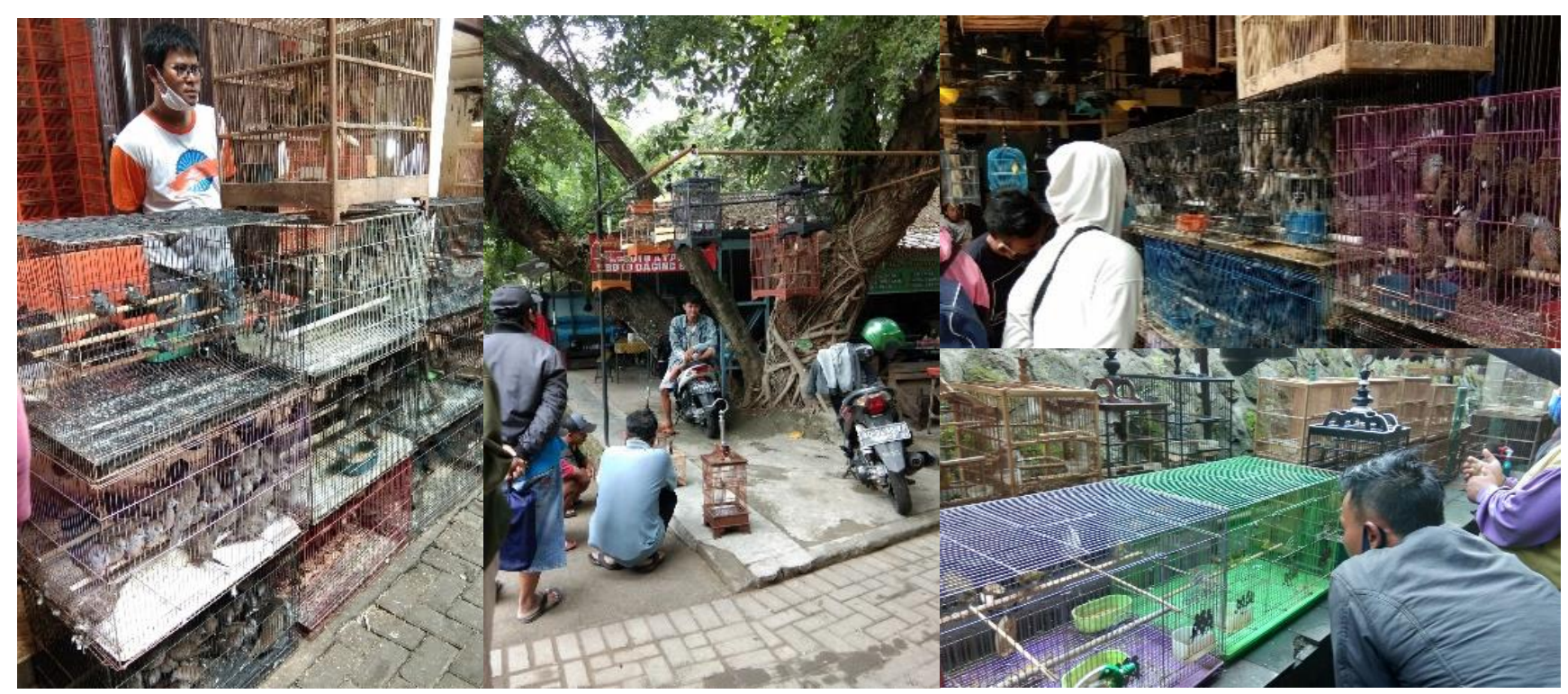

Figure 4. Activity of bird traders and bird buyers

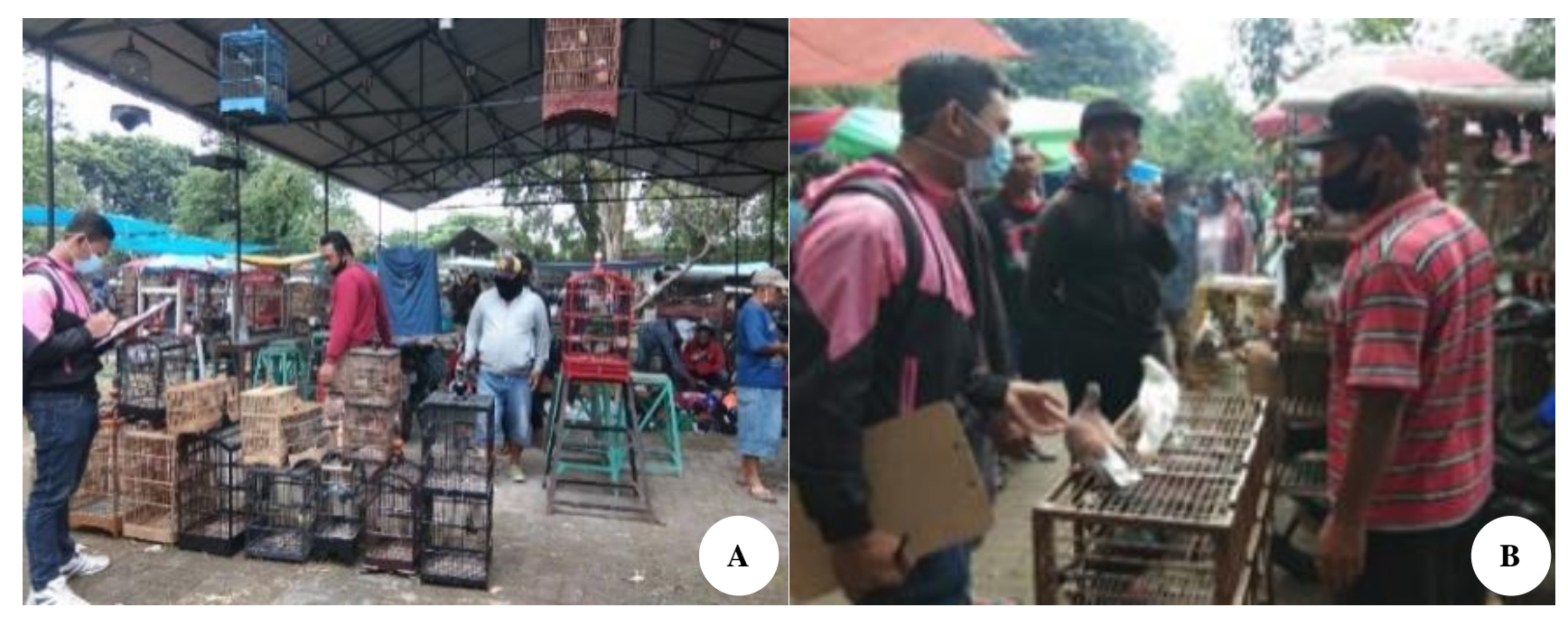

Figure 5. Field research processes. A. The identifying bird species; B. The interviewing the community of traders, buyers and others

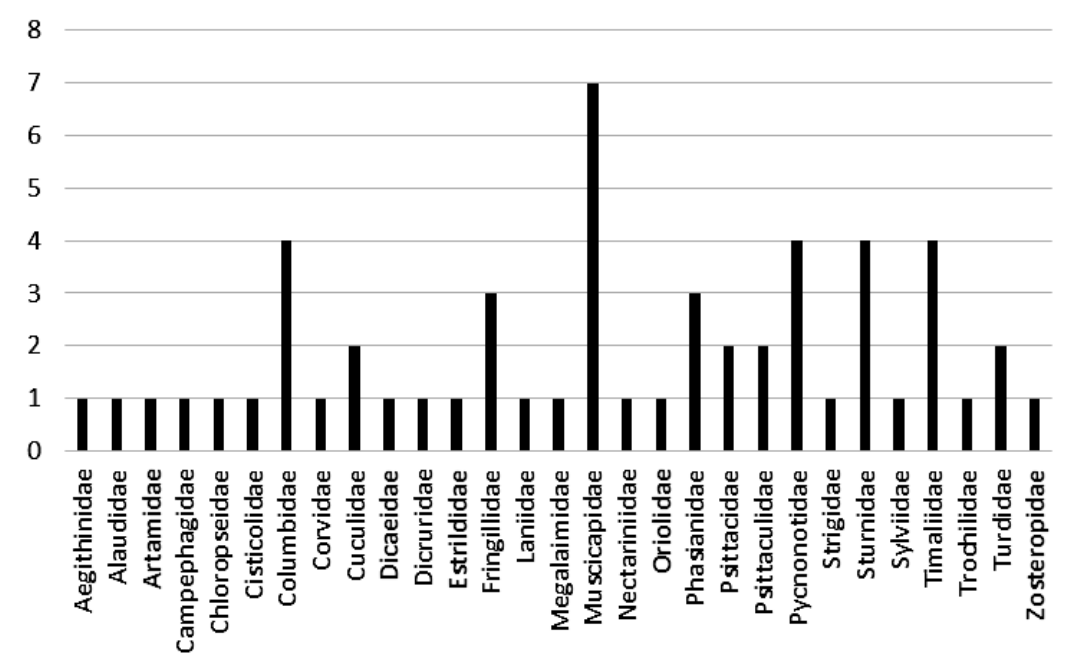

Figure 5. Families of birds offered in Depok bird market, Surakarta, Central Java, Indonesia 
Table 1. Various birds encountered in the bird market of Depok, Surakarta, Central Java, Indonesia based on conducted the field research December 2020 and January 2021

\begin{tabular}{|c|c|c|c|c|c|c|c|c|c|c|}
\hline Family & Species & $\begin{array}{l}\text { Indonesian } \\
\text { name }\end{array}$ & Common name & Bird sources & $\begin{array}{l}\text { Selling price } \\
\text { (Rupiah) }\end{array}$ & $\begin{array}{c}\text { IUCN } \\
\text { Conservation } \\
\text { status }\end{array}$ & $\begin{array}{l}\text { App. II of } \\
\text { CITES }\end{array}$ & $\begin{array}{c}\text { Permen } \\
\text { LHK } \\
\text { No.P.20/ } \\
2018\end{array}$ & $\begin{array}{c}\text { Endemicity } \\
*)\end{array}$ & $\begin{array}{c}\text { Population } \\
* *)\end{array}$ \\
\hline Aegithinidae & Aegithina tiphia & ipoh kacat & ommon lora & Wild hunting & $250.000-300.000$ & Least Concern & - & Unprotected & Non-endemic & Non-domina \\
\hline Alaudidae & Mirafra javanica & ranjangan & Torsfield's bushlark & Wild hunting & $200.000-1.500 .000$ & Least Concern & - & Unprotected & Non-endemic & Dominant \\
\hline Artamidae & Artamus leucorynchus & Kekep babi & $\begin{array}{l}\text { White-breasted } \\
\text { woodswallow }\end{array}$ & Wild hunting & $70.000-200.000$ & Least Concern & - & Unprotected & Endemic $^{1}$ ) & Non-dominant \\
\hline Campephagidae & Lalage nigra & Kapasan & Pied triller & Wild hunting & $40.000-65.000$ & Least Concern & - & Unprotected & Non-endemic & Dominant \\
\hline Chloropseidae & Chloropsis sonnerati & Cucak hijau & Greater green leafbird & Wild hunting & $500.000-3.000 .000$ & Endangered & - & Protected & Non-endemic & Non-dominant \\
\hline Cisticolidae & Prinia familiaris & Cimblek & Bar-winged prinia & Wild hunting & $80.000-500.000$ & Near Threatened & - & Unprotected & Non-endemic & Dominant \\
\hline Columbidae & Columba livia & Merpati & ock dove & Breeding & $20.000-50.000$ & Least Concern & - & Unprotected & Non-endemic & Dominant \\
\hline Columbidae & Geopelia striata & Perkutut & Zebra dove & Breeding & $45.000-200.000$ & Least Concern & - & Unprotected & Non-endemic & Dominant \\
\hline Columbidae & Spilopelia chinensis & Tekukur & Eastern spotted dove & Breeding & $10.000-80.000$ & Least Concern & - & Unprotected & Non-endemic & Dominant \\
\hline Columbidae & Treron vernans & Punai & Pink-necked green-pigeon & Wild hunting & $30.000-40.000$ & Least Concern & - & Unprotected & Non-endemic & Dominant \\
\hline Corvidae & Corvus corone & ragak & arrion crow & Wild hunting & $1.300 .000-2.000 .000$ & Least Concern & - & Unprotected & Non-endemic & Non-dominant \\
\hline Cuculidae & Cacomantis merulinus & edasih & aintive cuckoo & Wild hunting & $150.000-450.000$ & Least Concern & - & rotected & Non-endemic & Non-dominant \\
\hline Cuculidae & Centropus sinensis & But-but & eater coucal & Wild hunting & $55.000-600.000$ & Least Concern & - & Unprotected & Non-endemic & Non-dominant \\
\hline Dicaeidae & Dicaeum trochileum & Cabe jawa & $\begin{array}{l}\text { ded } \\
\text { er }\end{array}$ & Wild hunting & $20.000-80.000$ & Least Concern & - & Unprotected & End & Dominant \\
\hline Dicru & Dicrt & & so & & 20 & & - & & No & Nol \\
\hline Estrildidae & Lonchura leucogastroides & Pipit bondol & a munia & Wild hunting & $2.000-$ & Least Concern & - & ted & Ende & Dom \\
\hline Fringillidae & Serinus atrogularis & $\begin{array}{l}\text { Kenari teng- } \\
\text { gorokan hitam }\end{array}$ & Black-throated canary & Breeding & $600.000-2.000 .000$ & Least Concern & - & rotected & Non-endemic & Non- \\
\hline Fringi & Serinus & nari & and & & & $\mathrm{Le}$ & - & & No & Dol \\
\hline Fringillidae & Serinus leucopygius & nger & hite-rumped seedeater & Breeding & $450.000-1.500 .000$ & Least Concern & 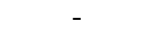 & tected & Non-endemic & Non-dominant \\
\hline Laniidae & Lanius schach & endet & ong-tailed shrike & Wild hunting & $50.000-250.000$ & Least Concern & - & Unprotected & Non-endemic & Non-dominant \\
\hline Megalaimidae & Megalaima lineata & altok & d barbet & Wild hunting & $350.000-800.000$ & Least Concern & 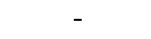 & & Idemic & Non-dominant \\
\hline Muscicapidae & Brachypteryx leucophrys & Cingcoang & Lesser shortwing & Wild hunting & $30.000-250.000$ & Not Evaluated & - & Unprotected & Non-endemic & Dominant \\
\hline Muscicapidae & Copsychus fulicatus & Murai india & Indian robin & Wild hunting & $1.500 .000-10.000 .000$ & Not Evaluated & 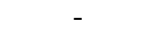 & Unprotected & Non-endemic & Non-dominant \\
\hline Muscicapidae & Copsychus saularis & Kacer & Drier & Breeding & -2.000 .000 & Least $\mathrm{Co}$ & 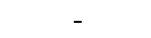 & ed & Non & inant \\
\hline Muscicapidae & Cyornis rufigastra & ledekan & Mangrove blue-flycatcher & Wild hunting & $35.000-250.000$ & Least & - & tected & Non- & Non \\
\hline Muscicapidae & Cyornis sanfordi & katan & Matinan flycatcher & Wild hunting & $30.000-80.000$ & Endangered & 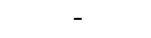 & Protected & Non-endemic & Non-dominant \\
\hline Muscicapidae & Erithacus rubecula & bin & Iropean robin & Wild hunting & $250.000-800.000$ & Least Concern & - & rotected & Non-endemic & Non-dominant \\
\hline Muscicapidae & Saxicola caprata & есu & ed bushchat & Id hunting & $100.000-350.000$ & Least Concern & - & rotected & Non-endemic & Non-dominant \\
\hline Nectariniidae & Leptocoma sperata & libri & rple-throated Sunbird & Wild hunting & $20.0000-350.000$ & Least Concern & - & rotected & Non-endemic & Dominant \\
\hline Oriolidae & Oriolus chinensis & Kepodang & Black-naped oriole & Wild hunting & $550.000-1.500 .000$ & Least Concern & - & rotected & Non-endemic & Non-dominant \\
\hline Phasianidae & Coturnix ypsilophora & Puyuh & Brown quail & Breeding & $10.000-30.000$ & Least Concern & - & Unprotected & Non-endemic & Dominant \\
\hline Phasi & Gallus gallus & Ayar & glefowl & Breeding & 0.000 & Least Concern & - & Unprotected & Non-endemic & Dominant \\
\hline Phasianidae & Meleagris gallopavo & Kalkun & Wild turkey & Breeding & $75.000-350.000$ & Least Concern & - & Unprotected & Non-endemic & Non-dominant \\
\hline
\end{tabular}




\begin{tabular}{|c|c|c|c|c|c|c|c|c|c|c|}
\hline Psittacidae & Eclectus roratus & Nuri & Moluccan eclectus & Wild hunting & $700.000-900.000$ & Least Concern & - & Protected & Non-endemic & Non-dominant \\
\hline Psittacidae & Melopsittacus undulatus & Parkit & Budgerigar & Breeding & $100.000-550.000$ & Least Concern & - & Unprotected & Non-endemic & Dominant \\
\hline Psittacidae & Agapornis sp. & Lovebird & Lovebird & Breeding & $35.000-1.500 .000$ & Least Concern & $\checkmark$ & Unprotected & Non-endemic & Dominant \\
\hline Psittacidae & Psittacula alexandri & Bayan & Red-breasted parakeet & Wild hunting & $400.000-700.000$ & Near Threatened & $\checkmark$ & Protected & Non-endemic & Non-dominant \\
\hline Pycnonotidae & Alophoixus bres & Cucak jenggot & Brown-cheeked bulbul & Wild hunting & $400.000-500.000$ & Endangered & - & Unprotected & Endemic ${ }^{3}$ ) & Non-dominant \\
\hline Pycnonotidae & Pycnonotus aurigaster & Kutilang & Sooty-headed bulbul & Wild hunting & $20.000-35.000$ & Least Concern & - & Unprotected & Endemic ${ }^{4}$ ) & Dominant \\
\hline Pycnonotidae & Pycnonotus jocosus & Kutilang jambul & Red-whiskered bulbul & Wild hunting & $90.000-100.000$ & Least Concern & - & Unprotected & Non-endemic & Dominant \\
\hline Pycnonotidae & Pycnonotus melanicterus & Kutilang emas & Black-capped bulbul & Wild hunting & $35.000-50.000$ & Least Concern & - & Unprotected & Non-endemic & Dominant \\
\hline Strigidae & Otus angelinae & Celepuk jawa & Javan scops-owl & Wild hunting & $70.000-150.000$ & Not Evaluated & - & Protected & Endemic $^{5}$ ) & Dominant \\
\hline Sturnidae & Acridotheres javanicus & Jalak hitam & Javan myna & Breeding & $75.000-150.000$ & Vulnerable & - & Unprotected & Endemic $^{4}$ ) & Dominant \\
\hline Sturnidae & Acridotheres melanopterus & Jalak putih & Black-winged myna & Breeding & $1.500 .000-3.500 .000$ & $\begin{array}{l}\text { Critically } \\
\text { Endangered }\end{array}$ & - & Unprotected & Endemic $^{6}$ ) & Dominant \\
\hline Sturnidae & Gracula religiosa & Beo & Common hill myna & Wild hunting & $1.500 .000-3.000 .000$ & Least Concern & $\checkmark$ & Protected & Non-endemic & Non-dominant \\
\hline Sturnidae & Gracupica contra & Jalak suren & Asian pied starling & Breeding & $350.000-875.000$ & Least Concern & - & Protected & Non-endemic & Dominant \\
\hline Sylviidae & Phylloscopus trivirgatus & Tralisan & Mountain warbler & Wild hunting & $60.000-100.000$ & Least Concern & - & Unprotected & Non-endemic & Dominant \\
\hline Timaliidae & Garrulax canorus & Wamby & Chinese hwamei & Breeding & $2.000 .000-6.500 .000$ & Least Concern & $\checkmark$ & Unprotected & Non-endemic & Non-dominant \\
\hline Timaliidae & Garrulax chinensis & Poksay hitam & $\begin{array}{l}\text { Black-throated } \\
\text { laughingthrush }\end{array}$ & Wild hunting & $300.000-3.000 .000$ & Least Concern & - & Unprotected & Non-endemic & Non-dominant \\
\hline Timaliidae & Leiothrix argentauris & Panca warna & Silver-eared mesia & Wild hunting & $100.000-200.000$ & Least Concern & $\checkmark$ & Unprotected & Non-endemic & Non-dominant \\
\hline Timaliidae & Malacocincla sepiaria & Pelanduk semak & Horsfield's babbler & Wild hunting & $100.000-250.000$ & Least Concern & - & Unprotected & Endemic ${ }^{4}$ ) & Dominant \\
\hline Trochilidae & Anthreptes malacensis & Madu kelapa & $\begin{array}{l}\text { Brown-throated } \\
\text { sunbird }\end{array}$ & Wild hunting & $35.000-75.000$ & Least Concern & - & Unprotected & Non-endemic & Dominant \\
\hline Turdidae & Geokichla citrina & Anis merah & Orange-headed thrush & Breeding & $850.000-2.500 .000$ & Least Concern & - & Unprotected & Non-endemic & Non-dominant \\
\hline Turdidae & Geokichla interpres & Anis kembang & $\begin{array}{l}\text { Chestnut-capped } \\
\text { thrush }\end{array}$ & Breeding & $700.000-2.000 .000$ & Endangered & - & Unprotected & Non-endemic & Non-dominant \\
\hline Zosteropidae & Zosterops palpebrosus & Kacamata teler & Indian white-eye & Wild hunting & $40.000-350.000$ & Least Concern & - & Unprotected & Endemic $^{4}$ ) & Dominant \\
\hline
\end{tabular}




\section{Conservation status and endemicity of birds traded in Depok Market}

The Depok market traded 55 bird species from 29 families. Out of these species checklists, a species is listed as critically endangered, 4 species as endangered, a species in vulnerable category, 2 species in near threatened status, and the remaining species in the least concern and not evaluated according to IUCN Red List (Kasambe 2014). In addition, 10 species are endemic to Indonesia (Table 1).

\section{IUCN RedList}

This study found a critically endangered bird species traded in Depok market, namely Acridotheres melanopterus that is also prohibited from being traded according to the Indonesian government regulation. Even though this species is worth relatively high (about Rp. 1.500.000-3.500.000), it could be easily encountered in this market, indicating that the demands from the consumer are also high. Study conducted by Shepherd et al. (2015) stated, the most significant selling number of $A$. melanopterus was in Jakarta bird markets in the price range of Rp. 2.500.000-3.000.000 each. This species, commonly known as Black-winged Myna, is considered as a species with a higher price compared to another species for instance Lanius schach (Nijman et al. 2021a). A. melanopterus has experienced dramatically declining trend since it was listed in Least Concern category by 1998, yet the status has been worsening recently (Nijman et al. 2017). In addition, in Depok market, there were four species listed as endangered species in IUCN Red List, namely Geokichla interpres, $C$. sonnerati, $C$. sanfordi. Unfortunately, only 2 out of 4 are protected by the nation rule. They are worth between $\mathrm{Rp} .400 .000$ to $\mathrm{Rp}$. 3.000.000, while $C$. sanfordi is the exception as it can be purchased only with Rp. 30.000-80.000.

Subsequently, Acridotheres javanicus which has been listed as vulnerable species can be easily encountered in this market. It used to be everpresent mainly in Malaysia and Singapore, but currently, it is rare to be encountered in the wild, even on its origin in Java (Chng et al.2016). The rapid decline might be caused by over-capture and trading in the past years, and it has been declared by Irham et al. (2020) in their study in Jambi by 2017, A. javanicus or locally known as Jalak hitam became the highest traded species sold more than 2500 individuals. Aside from that, Psittacula alexandri status has been raised from least concern to near threatened due to its declining population (Kasambe 2014). In Indonesia, this species is categorized as a protected animal, yet it still can be found traded in bird market and is worth from Rp. 400.000 to Rp. 700.000. Another species considered as least concern was Geokichla citrina. This species sale in Bali market showed an increasing trend in the past years and it might be soaring high in the future (Chng et al. 2018). Although this species had a low abundance in the Depok market, the increasing trend might occur if there is no strict regulation to fulfill the community demands.

Most of the birds traded in this market were least concern and widely available. However, there is still any possibility of downward trend in the number of species in the future. It has been predicted in a study by Yohanna et al. (2021) carried in Jambi market. It showed that unprotected birds became less available on market during five-year investigation that might be caused by overharvest of those species in nature. The government rules only drive captivation shifting from protected species to unregulated species, without completely stopping the species overexploitation (Nijman et al. 2021a).

\section{Appendix II of Cites}

At the Depok bird market, 5 bird species categorized in Appendix II of Cites, namely Garrulax canorus, Psittacula alexandri, Agapornis sp., Gracula religiosa, and Leiothrix argentauris.

Garrulax canorus encountered during this survey is included in Appendix II of CITES although the status is least concern based on the current IUCN assessment. It was the Chinese government that proposed G. canorus or Chinese Hwamei, which is native to this country and Vietnam, be listed in Appendix II due to surge of international trading (Shepherd et al. 2020). Years later, based on that study, the export trend mainly from China and Hong Kong has declined extensively because of the implementation of this rule along with local regulation.

\section{Permen LHK P.20/2018}

Seven bird species traded in Depok market are protected by the Indonesian Ministry of Environment and Forestry Regulation No. P.20/ MENLHK/setjen/Kum.1/6/ 2018. Those species are Otus angelinae, P. alexandri, A. melanopterus, Chloropsis sonnerati, Cyornis sanfordi, Eclectus roratus, and G. religiosa (Figure 6). Those species were mostly less abundant in Depok market, so those are defined as non-dominant (Table 1). According to the rule, those protected birds are prohibited to raise and trade both in the forms of living birds or dead specimens without permission from the government (Department of Forestry 2007). However, G. religiosa became one of the most popular pets in several major cities in Indonesia and it is called a unique species (Jepson and Ladle 2009). There is no doubt that although some species have been protected by law in Indonesia, those species are still predominantly sold in many bird markets.

\section{Endemicity}

Regarding endemicity, 10 species are considered as native to Indonesia, namely Artamus leucorynchus, Dicaeum trochileum, Lonchura leucogastroides, Alophoixus bres, Pycnonotus aurigaster, O. angelinae, A. melanopterus, A. javanicus, Malacocincla sepiaria, and Zosterops palpebrosus. However, only one of them is protected under Indonesian regulation. Herliansyah and Fitria (2018) reported that $A$. bres was profoundly affected by clear-cutting activity in Central Kalimantan. The result was similar to the $M$. sepiaria that significantly impacted not only by logging activity but also by parasites (Messina et al. 2021). On the other hand, increasing demand for $O$. angelinae (Javan scops-owl) was reported to be caused by the popularity of Harry Potter movies that depicted owls as companions (Nijman and Nekaris (2017). 


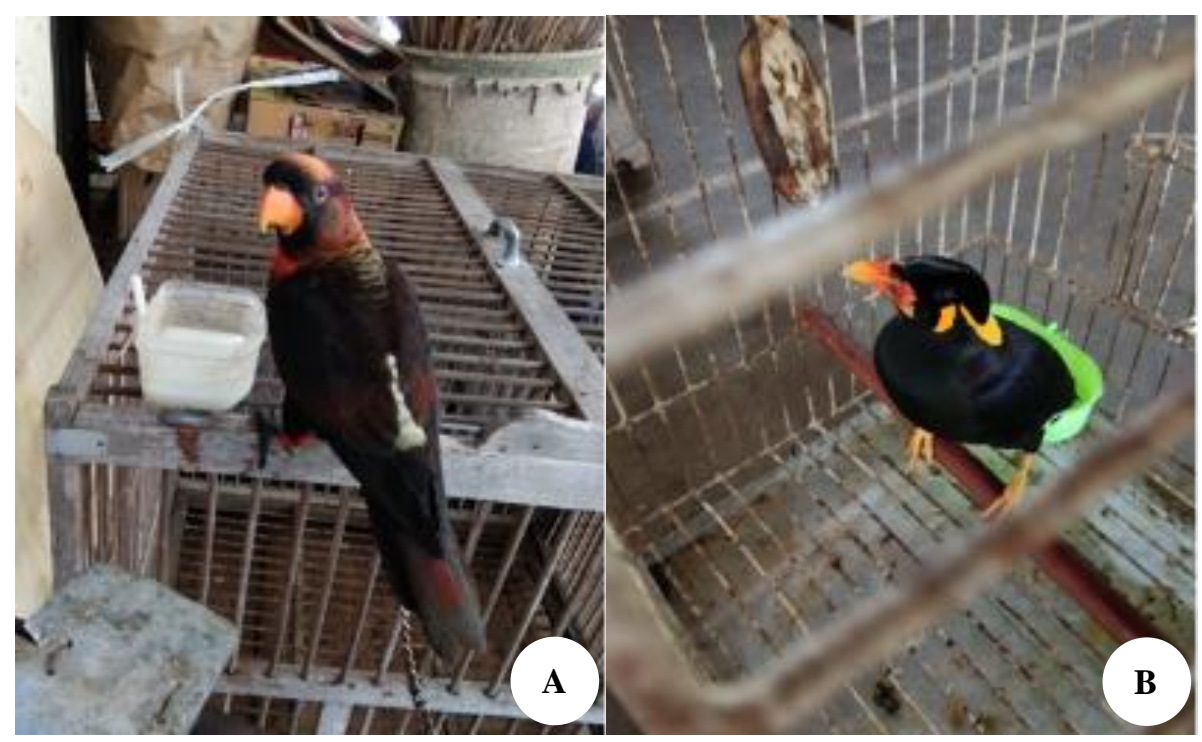

Figure 6. A. Eclectus roratus; B. Gracula religiosa

\section{Potential invasiveness}

Bird invasiveness in Indonesia is rarely discussed. Yap and Sodhi (2004) reviewed bird invasiveness in Southeast Asia. According to their study, 6 bird species in the Depok market are potentially invasive, namely: A. javanicus, Columba livia, Geopelia striata, P. alexandri, Pycnonotus aurigaster, and Pycnotus jocosus.

Yap and Sodhi (2004) include P. alexandri in the list of invasive bird species. This bird can escape from the cage, and inhabit secondary forests, woodland near cultivated areas, and mangroves. It can form flocks and settle in an area. It feeds on seeds, nuts, fruits, berries, flower nectar, and leaf buds. The nest is hole, commonly in trees; lay 3 to 4 eggs. Potential as a pest of rice plants. Ironically, $P$. alexandri is a threatened species, which is categorized as near threatened by IUCN, included in Appendix II by Cites and classified as a protected species by Indonesian Ministry of Environment and Forestry Regulation (No. P.20/ MENLHK/setjen/Kum.1/6/2018).

Meanwhile, G. striata is convincing and possible to be approached by humans, and well adapted to exploiting human-altered habitats. C. livia has strong commensal bonds with humans; considered a nuisance because it fouling of buildings and other structures with its droppings; can become agricultural pests; but also useful as food, bioindicator and for the study of avian biology. A. javanicus is tolerant of human presence; disturbing human occupants near communal nests; it droppings contaminate buildings and cars. $P$. aurigaster and $P$. jacobsus have both beneficial and detrimental impacts on agriculture and forestry. They can cause some damage to fruit and vegetable gardens, but also suppress the growth of insect pests (Yap and Sodhi 2004). Basically, invasive bird species are birds that adapt to human-altered habitats and cause harm.

\section{Selling price}

The price of a bird in Depok market varied from Rp. 2000 to Rp. 10.000.000. The cheapest species was Lonchura leucogastroides, only valued at Rp. 2000-Rp. 3000 each individual (Table 1). This species commonly known as Javan munia is endemic to Indonesia (Kurnianto and Kurniawan 2013) and is widely spread mainly in the west area of this country. Its vast distribution is due to excellent adaptability as this species does not require a particular area and nest material for nesting.

On the contrary, Copsychus fulicatus became the most costly bird species in Depok market, reaching up to Rp. 10.000.000 per individual followed by $G$. canorus as the second most expensive during this study that was individually offered from Rp. 2.000.000 to Rp. 6.500.000. Both are non-native species.

According to the direct survey, the factors determining the bird price are mostly the attractiveness of the bird's singing, feather color and behavior. These results were in accordance with studies of Regueira and Bernard (2012) and Chng et al. (2016) that bird price does not have a relation with their conservation status, but it is mostly determined by the bird's physical appearance and voice. In contrast, a study conducted by Siriwat and Nijman (2020) stated that bird price has a strong correlation with the IUCN status. It means as the species has a declining trend in its abundance in nature, it will be offered at a higher cost. Besides, the price is also determined by the bird's conditions. Generally, the bird which is caught from wild nature and directly sold to the bird markets will have a cheap price, although it is categorized as the songbirds because the trader or bird hunter does not need to take care of the new bird as it is immediately sold. Caring for new bird requires a huge effort to provide its food and poses a high risk that the bird gets sick or dies due to its inability to adapt to living in a cage; this risk has an impact on its price. As stated by Peng and Broom (2021), 75-90\% of 
wild-caught birds die before the point of sale. This argument is supported by the finding of Wiedarti et al. (2016) that maturity and adaptive aspects also cause the price range in bird trading to become much higher. Gender is also mentioned as a determinant factor of bird prices in Depok market. Male birds are more expensive than female because they have more attractive feather color and have more pleasant voices that makes them usually involved in the bird song contest. A study by Dai and Zhang (2017) mentioned the same result that male birds are considered more expensive compared to females because they have better singing abilities.

The bird species traded on the bird market can also be classified by bird traders into two main groups: songbirds and non-songbirds. This finding is supported by de Oliveira et al. (2020) research conducted in Brazil showing that there was a classification of birds based on their vocalization because the voice is the major determinant for buyer decision-making to purchase birds and is essential for traders to determine the price. Grouping the birds based on certain criteria can facilitate the buying and selling process. Various species of birds traded in the Depok bird market involved in contest included $C$. fulicatus, $C$. saularis, Agapornis sp., C. sonnerati, P. familiaris, $S$. canaria, L. sperata, and Z. palpebrosus. Three of them were encountered in songbird competition in Jabodetabek area (Angguni et al. 2020) with the most common bird found being Agapornis sp. In Depok market, those birds were sold at a price range of Rp. 20.000 to Rp. 10.000.000 (Table 2), with L. sperata became the cheapest songbird. The traders suggested that the price offered also depends on achievement they get in songbird competitions.

Another contest is flying race, which is usually involving C. livia. Referring to the bird traders in Depok market, $C$. livia or Doves are separated from their capability on flying competition: ordinary and racing dove. The members from the former group are never involved in flying races, while the latter group usually consists of doves which have participated in racing contests. Furthermore, racing doves can also be divided into two groups by their flying abilities, which are tall flying and low flying racing doves. The tall flying racing dove can fly about $150 \mathrm{~m}$ above the ground, while the low flying racing dove can only fly about 2-3 $\mathrm{m}$ above the ground (Zebua et al. 2016). There are many urban citizens that are fond of this bird racing, hence the dove species are widely traded in most bird markets. Choosing the winner of a certain bird flying racing takes several rounds, the winner of bird competition usually has an increased selling price.

\section{Market sustainability}

Based on marketed bird sources, only one-third of bird species (18 out of 55) come from breeding farms, the rest come from wild hunting (Table 1). The dominance of the bird supply from wild hunting is very concerning for the sustainability of trade, because the numbers cannot be ascertained and can accelerate the extinction of birds in the wild. Therefore, it is necessary to increase the supply of birds from breeding farms.
Table 2. Species of birds traded in Depok bird market involved in songbird contests

\begin{tabular}{lll}
\hline Bird species & Selling price (Rupiah) & $\begin{array}{l}\text { Conservation } \\
\text { status }\end{array}$ \\
\hline Leptocoma sperata & $20.0000-350.000$ & Least Concern \\
Agapornis sp. & $35.000-1.500 .000$ & Least Concern \\
Zosterops palpebrosus & $40.000-350.000$ & Least Concern \\
Prinia familiaris & $80.000-500.000$ & Near Threatened \\
Serinus canaria & $170.000-2.500 .000$ & Least Concern \\
Copsychus saularis & $350.000-2.000 .000$ & Least Concern \\
Chloropsis sonnerati & $500.000-3.000 .000$ & Endangered \\
Copsychus fulicatus & $1.500 .000-10.000 .000$ & Not Evaluated \\
\hline
\end{tabular}

Most endangered bird species in this market that are listed in the IUCN, Appendix II or Permen LHK P.20/2021 originate from wild capture; but but some are from breeding captivity, namely A. melanopterus (CR) and $G$. interpres (En). A. melanopterus is the dominant species in this market. Meanwhile, C. sonnerati (CR), C. sanfordi (CR), and $A$. bres (CR) were still obtained from wild hunting. The last two species are also listed as protected species by Permen LHK P.20/2021. Other bird species protected by this regulation but still supplied from wild hunting are E. roratus, G. religiosa, and P. alexandri. The last two species are also listed in Appendix II of Cites. Another species that is also listed in Appendix II but is traded from wild hunting is L. argentauris. Meanwhile, Agapornis sp. and G. canorus that also listed in Appendix II, were obtained from breeding captivity. Agapornis sp. is the dominant species in the market.

The source of birds is very crucial for the sustainability of trading system in the bird market. The supply of birds that rely on wild hunting is particularly vulnerable due to the decline in bird populations in rural ecosystems, which are the main suppliers for the bird market. Therefore, the source of birds from breeding captivity should be increased. Bird trade in the bird market must be based on the concept of sustainable development, both economically, socially, and environmentally (Iskandar et al. 2019).

\section{Naming and bird classification}

Depok market is situated in Central Java, thus bird naming is highly associated with the Javanese culture. Birds are called manuk in Javanese and burung in Indonesian. Referring to Forth (2015), ethnographic conversation generated bird information in small communities, thus it can vary from one location to another. Traditional folk is suggested to have a profound role in the naming of bird species as well, such as found in Agnihorti and Si's (2012) study in an ethnic group of India named Solega regarding how a companion between birds and humans was depicted in folklores impact on bird ethnobiological nomenclature. In line with that, most birds traded at the Depok bird market have local names that have been passed from generation to generation. The naming of species is based mainly on bird vocalization, feather color, morphological characteristics, habitat, and distinctive behavior. It can be seen that most bird folk taxonomy 
involves sensory observation of specific features, and thus it is easy to remember.

The birds can be classified locally by informants (folk classification) based on its voice, then the given name usually imitates or is similar to the regarded species. For instance, $S$. chinensis are called Tekukur because it sounds Terkukuuu..kuk...Terkukuuu...kuk. Moreover, Aegithina tiphia traditionally known as Cipoh kacat as a result of the voice it has (Ciiiii-paw) (Muhammad et al. 2020). Pipit bondol is a name referring to L. leucogastroides because it sounds Priiit.....Priitt...Priitt. All these common local names are based on the voices the people have traditionally heard according to the local Javanese community.

Several species of birds are named based on their feather color. Commonly, the name consists of the type of color that the bird has. For example, $C$. sonnerati is widely known as cucak ijo (ijo means green) as its feathers is dominated by green color. Panca warna is a name referring to L. argentauris (Panca means five and warna means color) because this species has feathers with multiple pigmentations. Subsequently, A. melanopterus is called jalak putih because its body and wings are white (Vernia et al. 2018). Cabe Jawa (D. trochileum) has bright red or orange on its chest (Rahadian et al. 2018), thus people find it is similar to cabe (chili) color and Jawa refers to its origin which is native to this region. Moreover, kapasan is a common name of L. nigra as people consider its color, which is dominated by clean white, is quite similar to the color of kapas (cotton). The similarity of special feature on Z. palpebrosus, which is white circle around the eyes, with eyeglasses which means in Indonesian is kacamata makes this species traditionally known as kacamata.

Morphological characteristic is also useful in naming bird species. A. bres is commonly called cucak jenggot because it has particular white characteristic on its chin and looks like beard (jenggot). Similarly, Pycnonotus jocosus with a pointed black crest leads to its local common name as kutilang jambul (jambul means crest).

Bird naming according to the habitat that has been mentioned also refer to O. angelinae as Celepuk Jawa because it is from Java Island. In addition, Murai India is a common name to call $C$. fulicatus because this bird is native to Indian subcontinent region (Praveen et al. 2020). Distinctive behavior is also a factor in bird naming. Anthreptes malacensis, for instance, is commonly known as burung madu kelapa because of its role as pollinator and it only eats madu or nectar (Ayat and Tata 2015). A. malacensis frequently encountered amongst flowers and flowering trees.

Apart from mentioned factors, the current trend also leads the way people named certain species. As Harry Potter movies gained huge popularity in Indonesia, lots of bird traders offered wide range of owl species and called them as Burung Harry Potter or Harry Potter birds no matter of what species they were (Nijman and Nekaris 2017).

\section{Market chain system and conservation implication}

The supply of birds in this market comes from both breeders and also bird hunters. They sell their captive breeding birds to traders at a standard price, and then the bird sellers resell them at a higher price. However, bird supply from breeders only accounts for approximately $30 \%$ since only a small number of them offer their captive birds, whereas the number of birds that come from hunters is relatively large as suppliers come from different regions. Thus, birds sold in this market are commonly caught from the forests. Merchants collect huge orders because they anticipated the number of deaths during the trip as the birds traded usually come from other cities where the population is still high. Then, the rest of birds offered come from local community with a percentage of around $10 \%$. We obtained this fact from a bird trader who has been selling at the bird market in Depok for several years.

Local inhabitants do bird hunting only on a small scale because the number of bird species that have a selling value has decreased a lot. They hunt for hobbies, fill their spare time, and only few of them consider this activity as a source of income due to unstable demand. In contrast, they prefer to raise and take care of birds themselves as later on, the birds can be sold at a higher price (especially for songbirds). Therefore, local hunters are relatively few compared to hunters from outside the region such as Pacitan, Wonogiri, Banyuwangi, Yogyakarta, Ponorogo, and Malang. Meanwhile, the traders from other islands usually come from Sumatra, Kalimantan and Lombok. The bird hunters in the Depok market stated that every bird they got from hunting must be examined for its quality and classification stage first. In other words, they sorted out which birds were in excellent condition and which that did not meet the criteria, and then sent the high-quality ones to sellers.

There is no doubt that bird keeping and trading have a high correlation with bird diversity in nature. As those activities are deeply rooted in culture, an approach involving cultural aspect needs to be taken into account. Jepson and Ladle (2009) argue that fines and law are considered by Indonesian as the ultimate way to tackle this issue. However, we argue that precaution steps need to be done before applying punishment. Thus, social and cultural involvement is considered to have a bigger impact on bird conservation. For instance, raising people's awareness about the importance of bird's role in nature through education by NGOs or the authorities is expected to lead behavioral change and to discourage people from selling and trading wild-captured birds (Bergin et al. 2017). Another method is using local wisdom approach. Turdus poliocephalus or Asian Thrush is considered as a sacred animal in Lawu Mountain, Central Java. It is widely believed that $T$. poliocephalus will acts as a guide to mountain climbers, thus it is prohibited to disturb this bird (Annisa 2018). Additionally, certain animals are protected by customary law as a local belief. Rhinoplax vigil or rangkong is believed by Rimba tribe in Jambi to have role in delivering messages to the god or a higher being. If this bird is disturbed or even killed, it will get god's curse (Novriyanti et al. 2014). An example from Ethiopia also suggests that local wisdom is also used to make conservation planning of the Northern Ground-hornbill (Bucorvus abyssinicus) (Asefa 2021). Those examples are 
considered as effective solutions as prevention steps to lowering the bird-killing and hunting rate.

This study concluded that the Depok bird market traded many species of birds, mostly supplied from rural areas and some of them are protected nationally and internationally. This bird trading is deeply rooted in local culture, so the conservation of birds should involve local participation instead of using repressive actions.

\section{ACKNOWLEDGEMENTS}

The authors would like to thank the informants of bird traders of the Depok Bird Market, Surakarta, Indonesia who kindly provided valuable data for this research. And, thanks to friends/colleagues and all those who have helped and supported the completion of this article.

\section{REFERENCES}

Alcantara-Salinas G, Ellen RF, Valinas-Coalla L, Caballero J, ArguetaVillamar A. 2013. Alternative ways of representing Zapotec and Cuicatec folk classification of birds: a multidimensional model and its implications for culturally-informed conservation in Oaxaca, México. J Ethnobiol Ethnomed 9 (81): 1-16. DOI: 10.1186/1746-4269-9-81.

Agnihorti S, Si A. 2012. Solega ethno-ornithology. BioOne Complete 32 (2): 185-211. DOI: 10.2993/0278-0771-32.2.185.

Alves RRN, Leite RCL, Souto WMS, Bezerra DMM, Loures-Ribeiro A 2013. Ethno-ornithology and conservation of wild birds in the semiarid Caatinga of Northeastern Brazil. J Ethnobiol Ethnomed 9 (14): 1 12. DOI: $10.1186 / 1746-4269-9-14$.

Angguni T, Mulyani YA, Mardiastuti A. 2020. Bird species contested at songbird competition in Jabodetabek Region, Indonesia. IOP Conf Ser Earth Environ Sci 762: 1-7. DOI: 10.1088/17551315/762/1/012014.

Annisa. 2018. Representasi mitologi Gunung Lawu dalam novel Aroma Karsa karya Dee Lestari. Prosiding Seminar Nasional Bahasa dan Sastra 1: 26-39. DOI: 10.24114/gondang.v2i2.11683. [Indonesian]

Asefa A. 2021. Exploration of human-bird relationships: Oromo proverbs associated with the Northern Ground-hornbill in Ethiopia. 4 (1) 100192. DOI: 10.1016/j.ssaho.2021.100162.

Ayat A, Tata HI. 2015. Diversity of birds across land use and habitat gradients in forests, rubber agroforests and rubber plantations of North Sumatra. Indones J For Res 2 (2): 103-120. DOI: 10.20886/ijfr.2015.2.2.103-120.

Burivalova Z, Lee TM, Hua F, Lee JSH, Prawiradilaga DM, Wilcove DS. 2017. Understanding consumer preferences and demography in order to reduce the domestic trade in wild-caught birds. Biol Conserv 209: 432-431. DOI: 10.1016/j.biocon.2017.03.005.

Chng SCL, Guciano M, Eaton JA. 2016. In the market for extinction: Sukahaji, Bandung, Java, Indonesia. BirdingAsia 26: 22-28.

Chng SCL, Krishnasamy K, Eaton JA. 2018. In the market for extinction: The cage bird trade in Bali. Forktail 34: 35-41.

CITES (The Convention on International Trade in Endangered Species). 2021. Appendices I, II, and III. https://cites.org/eng/app/appendices.php.

Dai C, Chen Y, Zheng Q. 2021. The social and cultural importance of keeping wild birds as pets in an ethnic community in Guiyang City, China. Hum Ecol 49, 69-79. DOI: 10.1007/s10745-020-00208-7.

Dai C, Zhang C. 2017. The local bird trade and its conservation impacts in the city of Guiyang, Southwest China. Reg Environ Change 17 (6) 1763-1773. DOI: 10.1007/s10113-017-1141-5.

de Oliveira WSL, Borges AKM, de Faria Lopes S, Vasconcellos A, Alves RRN. 2020. Illegal trade of songbirds: an analysis of the activity in an area of Northeast Brazil. J Ethnobiol Ethnomed 16: 1-14. DOI: 10.1186/s13002-020-00365-5.

Department of Forestry. 2007. U Law Number 5 of 1990 Regarding the Conservation of Biological Natural Resources and Their Ecosystem. Department of Forestry, Jakarta. [Indonesian]
Fink C, Toivonen T, Correia RA, Di Minin E. 2021. Mapping the online songbird trade in Indonesia. Appl Geograph 134: 102505. DOI: 10.1016/j.apgeog.2021.102505.

Forth G. 2015. Eastern Sumbanese bird classification and nomenclature: Additions and revisions. Ethnobiol Lett 7 (1): 45-52. DOI 10.14237/ebl.7.1.2016.572.

Ghifari B, Hadi M, Tarwotjo U. 2016. Keanekaragaman dan kelimpahan jenis burung pada taman kota Semarang, Jawa Tengah. Jurnal Akademika Biologi 5 (4): 24-31. [Indonesian]

Hakim L, Abdoellah OS, Parikesit, Withaningsih S. 2020. Impact of agricultural type and hunting on bird communities of two villages in Bandung, West Java, Indonesia. Biodiversitas 21 (1): 57-66. DOI: 10.13057/biodiv/d210109.

Haryanta A, Nugroho D, Hardianto N. 2011. Pendataan dan Pengenalan Jenis Satwa Liar di Pasar Burung yang Sering Diperdagangkan. Wildlife Conservation Society, Bogor. [Indonesian]

Herliansyah R, Fitria I. 2018. Latent variable models for multi-species counts modeling in ecology. Biodiversitas 19 (5): 2085-4722. DOI: 10.13057/biodiv/d190538.

Indraswari K, Friedman RS, Noske R, Shepherd CR, Biggs D, Susilawati C, Wilson. 2020. It's in the news: Characterising Indonesia's wild bird trade network from media-reported seizure incidents. Biol Conserv 243: 1-12. DOI: 10.1016/j.biocon.2020.108431.

Irham M, Yohanna, Kurniawan PT. 2020, Transaction records as a tool for bird trade monitoring in supporting bird's conservation and sustainable use. IOP Conf Ser Earth Environ Sci 457: 1-7. DOI: 10.1088/1755-1315/457/1/012020.

Iskandar BS, Iskandar J, Partasasmita R. 2019. Hobby and business on trading birds: Case study in bird market of Sukahaji, Bandung, West Java and Splendid, Malang, East Java (Indonesia). Biodiversitas 20: 1316-1332. DOI: 10.13057/biodiv/d200522.

Iskandar J, Iskandar BS, Mulyanto D, Alfian RL, Partasasmita R. 2020. Traditional ecological knowledge of the bird traders on bird species bird naming, and bird market chain: A case study in bird market Pasty Yogyakarta, Indonesia. Biodiversitas 21 (6): 2586-2602. DOI: 10.13057/biodiv/d210631.

Iskandar J. 2014. Dilema antara hobi dan bisnis perdagangan burung serta konservasi burung. Chim Nat Acta 2 (3): 180-185. DOI: 10.24198/cna.v2.n3.9165.

Izzati U, Hasibuan HS. 2019. Riparian tree and bird diversity in Cisadane River, South Tangerang City, Indonesia. Biodiversitas 20 (2): 595603. DOI: $10.13057 /$ biodiv/d200241.

Jepson P, Ladle RJ. 2005. Bird-keeping in Indonesia: Conservation impacts and the potential for substitution-based conservation responses. Oryx 39 (4): 442-448. DOI: 10.1017/S0030605305001110.

Jepson P, Ladle RJ. 2009. Governing bird-keeping in Java and Bali: evidence from a household survey. Oryx 43 (3): 364-374. DOI : 10.1017/S0030605309990251.

Kamaludin A, Winarno GD, Dewi BS. 2019. Diversity of avifauna at the Elephant Training Center Way Kambas National Park. J Sylva Lestari 7 (1): 10-21. DOI: 10.23960/js11710-21.

Kasambe R. 2014. Updates in the IUCN Red List of threatened birds of India. Mistnet 15 (1): 10-16.

Kurnianto AS, Kurniawan N. 2013. The predicted distribution of Javan munia (Lonchura leucogastroides) in Indonesia based of behavior analysis in Kalibaru, Banyuwangi, East Java. Biotropika: J Trop Biol 1 (1): $1-5$.

Kurnianto AS. 2017. The traditional hunting on greater green leafbird (Chloropsis sonnerati) in East Java: A vulnerable situation for vulnerable bird. J Biol Res 23 (1): 13-19. DOI: 10.23869/bphjbr.23.1.20173.

Loss ATG, Neto EMC, Machado CG, Flores FM. 2014. Ethnotaxonomy of birds by the inhabitants of Pedra Branca Village, Santa Teresinha municipality, Bahia state, Brazil. J Ethnobiol Ethnomed 10 (55): 1-15. DOI: 10.1186/1746-4269-10-55.

MacKinnon J, Phillips K, Van Balen B. 2010. Birds of Sumatera, Java, Bali and Kalimantan. RCB-LIPI \& Birdlife Indonesia, Bogor.

Messina S, Edwards DP, van Houtte N, Tomassi S, Benedick S, Eens M, Costantini D. 2021. Impacts of selective logging on haemosporidian infection and physiological correlates in tropical birds. Int J Parasitol. DOI: 10.1016/j.ijpara.2021.07.003.

Muhammad GI, Mardiastuti A, Sunarminto T. 2020. Identification and classification of avifauna based on local knowledge at Gunung Pinang, Serang Regency, Banten. Zoo Indones 29 (2): 67-82. DOI: 10.52508/zi.v29i2.4034. [Indonesian] 
Mutiara D, Rizal S, Royan M. 2020. Jenis-jenis burung yang diperjualbelikan di pasar burung Palembang Sumatera Selatan. Sainmatika: J Ilmiah Matematika dan Ilmu Pengetahuan Alam 17 (1): 23-30. DOI: 10.31851/sainmatika.v17i1.3643. [Indonesian]

Newing H, Eagle CM, Puri RK, Watson CW. 2011. Conducting Research in Conservation: Social Science Methods and Practice. Routledge, London. DOI: 10.4324/9780203846452.

Nijman V, Ardiansyah A, Hendrik R, Langgeng A, Manson S, Hedger K, Imron MA, Nekaris KAI. 2021a. Trade in a small-range songbird, the Javan crocias, gives insight into the Asian Songbird crisis. J Asia-Pac Biodivers 14: 154-158. DOI: 10.1016/j.japb.2021.01.001.

Nijman V, Campera M, Ardiansyah A, Balestri M, El Bizri H, Budiadi B, Dewi T, Hedger K, Hendrik R, Imron MA, Langgeng A, Morcatty TQ, Weldon AV, Nekaris KAI. 2021b. Large-scale trade in a songbird that is extinct in the wild. Diversity $13(6)$ : 1-14. DOI: $10.3390 / \mathrm{d} 13060238$.

Nijman V, Nekaris KAI. 2017. The Harry Potter effect: The rise in trade of owls as pets in Java and Bali, Indonesia. Global Ecol Conserv 11: 84-94. DOI: 10.1016/j.gecco.2017.04.004.

Nijman V, Sari SL, Siriwat P, Sigaud M, Nekaris KAI. 2017. Records of four Critically Endangered songbirds in the markets of Java suggest domestic trade is a major impediment to their conservation. Birding Asia 27: 20-25.

Novriyanti, Masy'ud B, Bismark M. 2014. System and ethnic local values in wildlife utilization of Rimba tribe of Bukit Duabelas Jambi Province. J Penelitian Hutan dan Konservasi Alam 11 (3): 299-313. DOI: 10.20886/jphka.2014.11.3.299-313. [Indonesian]

Nurdin N, Nasihin I, Guntara AY. 2018. Pemanfaatan keanekaragaman jenis burung berkicau dan upaya konservasi pada kontes burung berkicau di Kabupaten Kuningan Jawa Barat. Wanaraksa 11 (1): 1-5. [Indonesian]

Pam GA. 2017. Ethno-ornithology and Conservation: Tradisional Ecological Knowlegde (TEK) of Birds among the Mushere and the Conservation of the Dulu Forest in Mushere, Plateau State Nigeria. [Thesis]. University of Oxford, London.

Peng S, Broom DM. 2021. The sustainability of keeping birds as pets: should any be kept? Animals 11: 582. DOI: 10.3390/ani11020582

Praveen J, Jayapal R, Pittie A. 2020. Taxonomic updates to the checklists of birds of India, and the South Asian region-2020. Indian Birds 16 (1): $12-19$.

Rahadian SR, Wiradarma H, Kurniawan A, Tamar IM. 2018. The species diversity of avifauna in Bukit Cinta Klaten in supporting the development of birdwatching area of Gunung Gajah Village Klaten. IOP Conf Ser J Physic 1217: 012164. DOI: 10.1088/17426596/1217/1/012164

Regueira RFS, Bernard E. 2012. Wildlife sinks: Quantifying the impact of illegal bird trade in street markets in Brazil. Biol Conserv 149: 16-22. DOI: 10.1016/j.biocon.2012.02.009.

Rumanasari RD, Saroyo S, Katili DY. 2017. Biodiversitas burung pada beberapa tipe habitat di Kampus Universitas Sam Ratulangi. J MIPA 6 (1): 43-46. DOI: 10.35799/jm.6.1.2017.16153. [Indonesian]

Sheldon FH, Lim HC, Moyle RG. 2015. Return to the Malay Archipelago: the biogeography of Sundaic rainforest birds. J Ornithol 156 (S1): 91113. DOI: $10.1007 / \mathrm{s} 10336-015-1188-3$.

Shepherd CR, Leupen BTC, Siriwat P, Nijman V. 2020. International wildlife trade, avian influenza, organised crime and the effectiveness of CITES: The Chinese hwamei as a case study. Global Ecol Conserv 23: 1-16. DOI: 10.1016/j.gecco.2020.e01185.

Shepherd CR, Nijman V, Krishnasamy K, Eaton JA, Chng SCL. 2015. Illegal trade pushing the Critically Endangered Black-winged Myna Acridotheres melanopterus towards imminent extinction. Bird Conserv Intl 26 (2): 147-153. DOI: 10.1017/S0959270915000106.

Siriwat P, Nijman V. 2020. Short communication: Wildlife trade shifts from brick-and-mortar markets to virtual marketplaces: A case study of birds of prey trade in Thailand. J Asia-Pac Biodivers 13: 454-461. DOI: $10.1016 /$ j.japb.2020.03.012.

Vernia RE, Tritto A, Abinawanto A, Winarni N, Mayasari N, Sedayu A, Bowolaksono. 2018. Morphological characteristic of black-winged myna (Acridotheres melanopterus). MATEC Web Conf 197: 1-5. DOI: $10.1051 /$ matecconf/201819706006.

Wiedarti S, Moerfiah, Sudrajat C, Iqbal GM. 2016. The diversity of bird species that are traded in the bird market in the city of Bogor, Indonesia. AIP Conf Proc 1744: 1-7. DOI: 10.1063/1.4953530.

Xayyasith S, Douangboupha B, Chaiseha Y. 2020. Recent surveys of the bird trade in local markets in Central Laos. Forktail 36: 47-55.

Yap CAM, Sodhi S. 2004. Southeast Asian invasive birds: ecology, impact and management. Ornithol Sci 3: 57-67.

Yohanna, irham M, Kurniawan PT. 2021. Monitoring of songbird trades in Jambi, Indonesia. IOP Conf Ser: Earth Environ Sci 690: 1-5. DOI: 10.1088/1755-1315/690/1/012035.

Zebua FE, Riyanti, Kurtini T. 2016. Perbedaan karakteristik tubuh merpati tinggi jantan dan merpati balap jantan lokal. J Ilmiah Peternakan Terpadu 4 (3): 244-248. [Indonesian] 